\title{
First report of Ascochyta dolomitica causing leaf spots on Hepatica acutiloba in the UK
}

B. Henricot*

\author{
Department of Plant Pathology, The Royal Horticultural Society, Wisley, Woking, Surrey, GU23 6QB, UK \\ *E-mail: beatricehenricot@rhs.org.uk
}

Received: 20 Sep 2010. Published: 03 Dec 2010. Keywords: Hepatica nobilis, Ranunculaceae, fungal plant disease

The genus Hepatica (Ranunculaceae) includes some 10 species which have long been cultivated for their early spring flowers. In May 2009, a diseased sample of Hepatica acutiloba was received at the advisory service of the Royal Horticultural Society. The leaves showed brown/black irregular leaf blotches carrying black fruiting bodies (Fig. 1A). Conidia were single septa, cylindrical, rounded at both ends and measured 8-13 $x$ 2-3 $\mu \mathrm{m}$ (Fig. 2). Pycnidia measured 140-190 $\mu \mathrm{m}$ in diameter (Fig. 3). The morphological characteristics fit the description of Ascochyta dolomitica which is recorded on Hepatica, Ranunculus and Clematis species in Europe and Asia (Mel'nik, 2000). A voucher specimen was deposited at the Royal Botanic Gardens, Kew, UK K(M)164724).

The ITS region was amplified using ITS 1 and ITS 4 primers (White et al., 1990) and sequenced (GenBank Accession No. HM754628). The sequence was unique when compared to other sequences in GenBank. The fungus was cultured in vitro on potato-carrot agar supplemented with ampicillin $(30 \mu \mathrm{g} / \mathrm{ml})$ and streptomycin sulphate $(133 \mu \mathrm{g} / \mathrm{ml})$, and sporulated after four weeks under near UV light $\left(16 \mathrm{~h}\right.$ photoperiod) at $22^{\circ} \mathrm{C}$. To fulfil Koch's postulates, Hepatica nobilis plants were dipped in spore suspension of $\sim 2$ x10spores $/ \mathrm{ml}$. The control plant was not inoculated. A plastic bag was placed on plants for $48 \mathrm{hrs}$ to maintain high humidity and favour infection. The plants were left outdoors where the temperature ranged from $12^{\circ} \mathrm{C}$ to $22^{\circ} \mathrm{C}$. After 20 days, the first leaf spots appeared on the inoculated leaves leading eventually to leaf death (Fig. 1B). The control plant remained healthy. Ascochyta dolomitica has been reported before in several European countries in Austria, Czechoslovakia, Germany, Latvia, Romania and Poland (Mel'nik, 2000; Farr \& Rossman, 2010) but this is the first record of Ascochyta dolomitica in the UK.

\section{Acknowledgements}

The author would like to thank Mrs Jenny Denton for her technical assistance.

\section{References}

Farr DF, Rossman AY, 2010. Fungal Databases, Systematic Mycology and Microbiology Laboratory, ARS, USDA. Retrieved July 15, 2010, from http://nt.ars-grin.gov/fungaldatabases/

Mel'nik VA, 2000. Key to the fungi of the genus Ascochyta Lib. (Coelomycetes). Mitteilungen aus Biologischen Bundesanstalt für Landund Forstwirtschaft. Heft 379: 1-192. (Translated into English by VA Mel'nik, U Braun and G Hagedorn.)

White TJ, Burns T, Lee S, Taylor J, 1990. Amplification and direct sequencing of fungal ribosomal genes for phylogenetics. In: Innis MA, Gelfand DH, Shinsky J, White TJ, eds. PCR protocols. A guide to methods and applications. San Diego, CA, USA: Academic Press, 315-322.
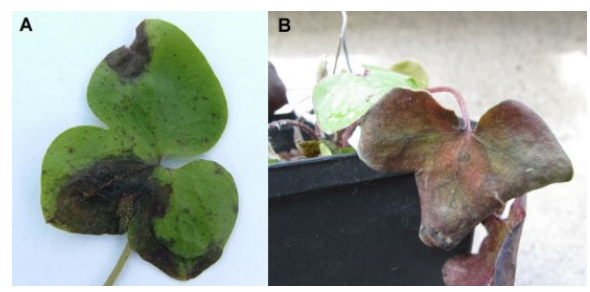

Figure 1

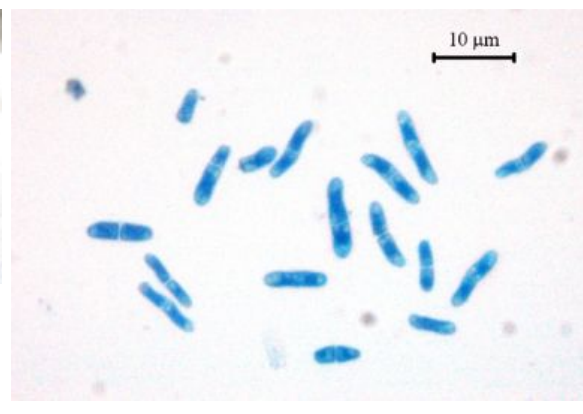

Figure 2

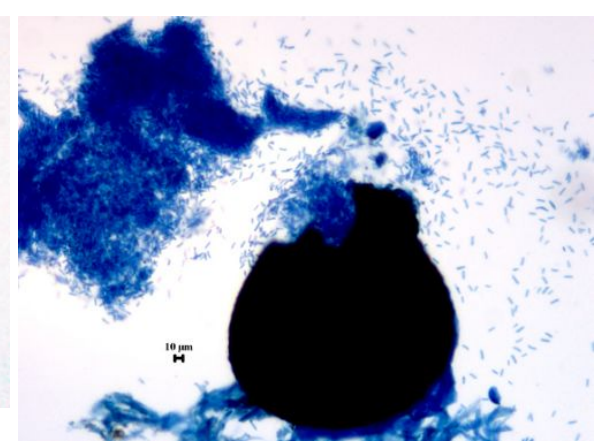

Figure 3

To cite this report: Henricot B, 2010. First report of Ascochyta dolomitica causing leaf spots on Hepatica acutiloba in the UK. New Disease Reports 22, 30. [doi:10.5197/j.2044-0588.2010.022.030] 